\title{
PERILAKU HIDUP BERSIH SEHAT PEKERJA SEKS KOMERSIAL SETELAH MENGIKUTI KONSELING DAN TES HIV/AIDS
}

\author{
Nila Titis Asrining Tyas ${ }^{1}$, Fitria Handayani ${ }^{*}$ \\ 1. Program Studi Ilmu Keperawatan Fakultas Kedokteran Universitas Diponegoro \\ Jl. Prof. H. Soedarto SH Tembalang, Semarang 50275, Indonesia \\ *Email: fitriaha@yahoo.co.id
}

\begin{abstract}
Abstrak
Konseling dan tes HIV/AIDS sukarela merupakan suatu pembinaan dua arah atau dialog yang berlangsung tak terputus antara konselor dan kliennya dengan tujuan untuk mencegah penularan HIV, memberi dukungan moral, informasi, serta dukungan lainnya kepada ODHA, keluarga, dan lingkungannya. Penelitian ini melibatkan 7 Pekerja Seks Komersial (PSK) sebagai partisipan. Pengumpulan data dengan wawancara mendalam yang dianalisis dengan content analysis. Hasilnya para PSK memaknai proses Konseling dan tes HIV/AIDS sukarela yang telah mereka jalani dengan tetap mempertahankan perilaku hidup bersih sehat mereka sehari-hari dan tetap mencari pelayanan kesehatan serta menjadi pendidik sebaya di lokalisasi. Pemerintah dan LSM terkait hendaknya turut memfasilitasi para PSK untuk mempertahankan perilaku hidup bersih sehat mereka setelah melakukan konseling dan tes berkelanjutan.
\end{abstract}

Kata kunci: konseling dan tes HIV/AIDS, perilaku hidup bersih sehat, Pekerja Seks Komersial

\begin{abstract}
Voluntary Counseling and Testing HIV/AIDS (VCT) is a two-way counseling or continuous dialogue between counselor and client to prevent HIV transmission, give moral support, information and other supports for people with HIV/AIDS, his family and the environment. The total participants in this research were 7 CSWs. The researcher used in-depth interview to collect the data, which were analyzed by content analysis method. The research showed that the meaning of VCT for CSWs themselves could kept their daily healthy behavior and healthy seeking and also became peer educators after following the VCT process. The government and the voluntary organizations which are concerned with CSWs and HIV/ AIDS should facilitate the CSW's efforts to keep their health oriented after doing VCT with continuous screening.
\end{abstract}

Keywords: Commercial Sex Workers (CSW), daily healthy behavior, VCT

\section{Pendahuluan}

Human Immunodeficiency Virus (HIV)/Acquired Immuno Deficiency Syndrome (AIDS) merupakan pandemi yang terjadi hampir di seluruh negara. Peningkatan jumlah orang dengan HIV/ AIDS dari 36,6 juta orang pada tahun 2002 menjadi 39,4 juta orang pada tahun 2004.

Pada tahun 2005 jumlah penduduk dunia yang terinfeksi HIV adalah 40,3 juta. Kasus baru yang ditemukan di seluruh dunia adalah 4,9 juta dan angka kematian karena AIDS sebanyak 3,1 juta (UNAIDS, 2008).

VCT merupakan singkatan dari Voluntary Counseling and Testing HIV/AIDS, artinya adalah melakukan konseling dan tes HIV/AIDS secara sukarela. Konseling adalah bimbingan dari konselor terhadap klien agar dapat memahami permasalahan perilakunya, mengambil keputusan terbaik yang didasarkan dari informasi sepadan dan objektif, kemudian menghilangkan perasaan khawatir berlebihan untuk melakukan tes dan mengetahui hasil tesnya (Sandy, 2008).

Seseorang yang mau dengan sukarela datang ke klinik dan melakukan konseling dan tes HIV/ AIDS sukarela (VCT) akan mendapat manfaat yang luar biasa. Bila hasil tes HIV pada orang tersebut negatif, maka ia akan merasa sangat bahagia dan bersyukur, sehingga ia akan lebih termotivasi untuk mengubah perilaku menjadi lebih sehat.

Penelitian pada beberapa negara menunjukkan bahwa klien dengan diagnosis negatif HIV/ AIDS akan menjadi orang yang berperilaku seksual secara sehat dan menghentikan injeksi narkoba. Kalaupun ada yang masih adiksi, maka ia sudah mengetahui cara menghindarkan diri dari risiko terinfeksi melalui jarumnya sendiri dan cara sterilisasinya (Sandy, 2008). 
Seseorang yang hasil tes HIV-nya positif, umumnya pada awalnya ia akan merasa sedih. Akan tetapi, selanjutnya dengan bimbingan konselor, ia akan menyadari dan memulai hidup dengan cara yang lebih sehat. Dengan bimbingan pula, ia akan membuat hidup lebih nyaman dan dapat melakukan rerorientasi hidup. Selain itu, ia akan melakukan hubungan yang aman atau bahkan tidak melakukan hubungan seksual sama sekali, sehingga ia sudah mencegah penularan HIV pada orang lain (Sandy, 2008).

Keragaman pemaknaan akan pengalaman memutuskan dan menjalani konseling dan tes HIV/ AIDS sukarela (VCT) ini mendorong peneliti mengkaji lebih dalam tentang pengalaman para PSK dalam memutuskan dan menjalani VCT. Gambaran atau deskripsi yang jelas mengenai pengalaman para PSK saat memutuskan dan menjalani VCT dilakukan dengan teknik wawancara mendalam kepada para PSK yang telah melakukan VCT.

Tujuan dari penelitian ini adalah untuk mendapatkan gambaran dan makna pengalaman PSK di Lokalisasi dalam memutuskan dan menjalani konseling dan tes HIV/AIDS sukarela (VCT). Manfaat penelitian ini bagi masyarakat adalah meningkatkan pengetahuan masyarakat mengenai kehidupan para PSK dan ODHA sehingga stigma negatif masyarakat terhadap keberadaan mereka berkurang bahkan hilang. Bagi profesi keperawatan adalah meningkatkan peran perawat dalam komunitas khususnya sebagai konselor untuk mengoptimalkan fungsi konseling dan tes HIV/AIDS sukarela (VCT) bagi para PSK.

\section{Metode}

Penelitian ini menggunakan metode penelitian kualitatif dengan pendekatan fenomenologis dengan mempelajari situasi dalam kehidupan sehari-hari dari sudut pandang orang yang mengalaminya. Jumlah partisipan dalam penelitian ini adalah 7 orang yang tinggal di lokalisasi dengan kriteria inklusi pernah melakukan konseling dan pemeriksaan HIV/AIDS sukarela (VCT) dan bersedia diteliti dengan menandatangani surat persetujuan.

Analisis data yang digunakan dalam penelitian ini adalah content analysis. Ada empat langkah proses kognitif dengan pendekatan integral dalam penelitian kualitatif, yaitu comprehending, synthetizing, theorizing, dan recontextualizing (Moleong, 2002).

Penelitian ini menganalisis data secara manual melalui empat langkah, yaitu pemrosesan satuan (unitying), kategorisasi, penafsiran/pemaknaan data, dan perumusan teori. Ada empat kriteria yang digunakan untuk menetapkan keabsahan data yaitu kepercayaan (credibility), keteralihan (transferability), kebergantungan (dependability), dan kepastian (confirmability). Peneliti juga berperan sebagai instrumen penelitian dalam penelitian kualitatif, sehingga subyektivitas dari peneliti perlu dihindari.

\section{Hasil}

\section{Karakteristik Partisipan}

Karakteristik ketujuh partisipan dalam penelitian ini adalah seluruh partisipan termasuk dalam kelompok usia produktif yaitu 19-46 tahun, berpendidikan antara SLTP hingga SMA, telah bekerja sebagai PSK antara 1-5 tahun dan lima di antaranya berperan sebagai peer educator dalam lokalisasi.

Hasil analisis terhadap tema-tema yang tersusun atas kategori data yang ditemukan dalam proses wawancara mendalam dalam penelitian ini meliputi:

\section{PSK mempertahankan perilaku mencari pelayanan kesehatan dan meningkatkan perilaku hidup bersih sehat (PHBS) setelah melakukan VCT}

Dalam wawancara mendalam PSK mengungkapkan bahwa setelah mereka melakukan VCT, mereka tetap mempertahankan perilaku mencari pelayanan kesehatan yang ada untuk mengetahui kondisi kesehatan mereka. Mereka juga mengalami peningkatan perilaku hidup bersih sehat (PHBS) sehari-hari untuk mempertahankan kesehatan mereka. Hal ini sesuai dengan pernyataan berikut:

\footnotetext{
"Saya 3 hari sekali cebok dengan air daun sirih itu tho, itu kan bisa membersihkan area kewanitaan. Lalu ganti celana dalam 2 kali sehari, pagi dan sore. Pokoknya ya semua yang dianjurkan dokter itu ya Saya lakukan. Kalo Kita screening itu kan selalu ada dokternya, ya dikasih tau di daerah kewanitaan tu ada lukanya atau lecet kan biar Kita tau” (P-5).
} 


\section{PSK menjadi Peer Educator (PE) tentang IMS dan HIV/AIDS bagi teman-teman seprofesinya setelah melakukan VCT}

Beberapa PSK yang telah melakukan VCT berperan sebagai Peer Educator (PE) mengenai IMS dan HIV/AIDS bagi teman-teman seprofesinya. PSK yang menjadi PE mendapatkan motivasi dari PKBI dan teman-teman seprofesinya. Hal ini senada dengan pernyataan partisipan berikut:

“...menjadi peer educator itu dorongannya... Pertama dari LSM juga, kedua dari temen ketigane memang waktu itu kan temen aku yang di sini pergi, udah nggak di sini, terus menggantikan, dulune yang jadi peer educator dia itu" (P-2).

\section{Keberhasilan PSK sebagai pendidik mengenai IMS dan HIV/AIDS bagi pelanggan}

Salah seorang PSK yang menjadi partisipan dalam penelitian ini mengungkapkan bahwa ia pernah mengajak beberapa pelanggannya untuk melakukan VCT.

Tindakan mengajak pelanggannya melakukan VCT ini merupakan salah satu manfaat VCT yang dijalani oleh PSK bagi pelanggan dengan menjadi pendidik mengenai IMS dan HIV/AIDS bagi pelanggan. Hal ini sesuai dengan pernyataan salah satu partisipan sebagai berikut:

“Aku sudah pernah bawa tamu-tamu Saya untuk VCT kok, Mbak. Jumlahnya ada 12...”

"Ya, Saya bilang: ya melindungi Anda ya melindungi Saya, walaupun Anda jajan ke sini tapi kita harus selalu jaga kesehatan gitu lho.."(P-6).

"Untuk mencegah HIV dan AIDS kita harus, kalau Anda mau melindungi Saya, Saya pun juga harus melindungi Anda begitu. Lindungi dia, lindungi Saya...”(P-6).

"Pertamanya Saya hubungi dulu lewat telepon, kan dia bilang VCT itu apa. Terus Saya bilang tes darah itu lho. Terus dia nanya, nanti hasilnya bisa langsung diketahui? Saya bilang bisa, langsung diketahui"(P6).

"Terus, anda berani ndak? Dia bilang berani. Ya terus Saya menghubungi tim dari PKBI: Mas ini Saya ada tamu yang mau ikut VCT. Lalu ditanya: Iya Mbak berapa orang? Lalu Saya diantar ke rumah sakit bersama dengan tamu-tamu Saya tadi” (P-6).
PSK yang menjadi PE dianggap menggurui oleh teman-teman seprofesinya ketika ingin menyampaikan informasi mengenai IMS dan HIV/AIDS

Dalam menjalani peran sebagai PE, para PSK mengalami beberapa hambatan dalam menyampaikan informasi mengenai IMS dan HIV/AIDS kepada teman-teman seprofesinya karena banyak teman seprofesinya yang menganggap para anggota $\mathrm{PE}$ menggurui mereka ketika para anggota PE tersebut menyampaikan informasi mengenai IMS dan HIV/ AIDS. Hal ini sesuai dengan pernyataan berikut:

“...tergantung orangnya. Ya kalau orang itu bisa diajak ngomong lha kalo nggak. Tapi kadang gini Mbak ada yang enak diajak ngobrol-ngobrol tapi ada juga yang bilang kalau Saya sok ngajari, bukan kadang sih Mbak, sering malah ada yang kayak gitu ke Saya. Jadi Saya juga liat situasi dan kondisi kalau mau ngobrol-ngobrol dengan temen-temen Saya. Saya kan juga harus sadar akan diri Saya juga, ntar jarkone iso ngajari ra iso nglakoni kan nggak enake itu juga tho Mbak" (P-7).

“...Saya kan juga anggota PE jadi sedikit banyaknya tu Saya tau berhubung tidak pengalaman mungkin ngomongnya itu susah tapi maksudnya itu tau gitu. Saya ditunjuk dari pusat PKBI. Maksudnya tu Saya mudeng, tau, tapi kalau untuk menyampaikan tu susah maklum kan Mbak Saya kan pendidikannya SD tu ibarat ndak punya... ya pokoknya Saya yang penting bagi Saya tu gini Mbak, Saya sudah tau maksudnya gitu aja udah, nanti kalo Saya menuntut itu kok nantinya takut ada yang bilang: halah gaya sok pengen tau, takutnya kayak gitu Saya malah nggak enak sendiri kalo ada yang kayak gitu. Ya apa adanya Saya lah" (PS-5).

\section{Pembahasan}

PSK mempertahankan perilaku mencari pelayanan kesehatan dan meningkatkan perilaku hidup bersih sehat (PHBS) setelah melakukan VCT

Perilaku mencari pelayanan kesehatan para PSK ditunjukkan dengan tetap rajin mengikuti screening IMS setiap bulan di area lokalisasi yang difasilitasi oleh PKBI. Selain itu, memeriksakan diri ke pelayanan kesehatan lain yang ada, seperti Puskesmas dan dokter. Pemeriksaan tersebut dilakukan ketika mereka merasakan adanya gangguan kesehatan dalam tubuh mereka. 
Peningkatan perilaku hidup bersih sehat mereka tampak pada usaha mereka untuk menjaga kebersihan area genitalia mereka dengan rajin mengganti celana dalam setiap hari serta rajin membersihkan area genitalia mereka menggunakan air rebusan daun sirih untuk mengurangiagen infeksius IMS.

Sandy (2008) menyebutkan bahwa ada seorang relawan pendamping ODHA mengungkapkan bahwa seseorang yang mau dengan sukarela datang ke klinik dan melakukan VCT akan mendapat manfaat yang luar biasa. Bila ia kedapatan negatif, orang akan sangat bahagia dan sangat bersyukur sehingga ia akan mudah sekali mengubah perilaku menjadi sehat.

\section{PSK menjadi Peer Educator (PE) IMS dan HIV/AIDS bagi teman-teman seprofesinya setelah melakukan VCT}

Dengan mengetahui begitu banyak faktor risiko dalam pekerjaan mereka serta adanya berbagai macam cara yang bisa mereka lakukan untuk mengantisipasinya maka para PSK dapat berbagi informasi kepada teman-teman seprofesi mereka agar mereka tetap terbebas dari penyakit IMS dan HIV/ AIDS.

Menurut mereka munculnya pendidik sebaya merupakan tindakan pencegahan yang efektif akan infeksi HIV/AIDS karena informasi mengenai HIV/ AIDS dan pencegahannya akan lebih mudah diterima oleh para PSK.

Hal tersebut akan mudah diterima oleh para PSK, jika diberikan oleh teman-teman seprofesi mereka yang memiliki kesamaan permasalahan kehidupan dan memahami komplikatifnya kehidupan mereka menjadi seorang PSK.

Salah satu manfaat dari peer educator adalah dapat menciptakan kerja sama dari populasi target yaitu komunitas PSK sendiri untuk berbagi mengenai pengalaman masa lalu yang mendasari mereka berprofesi sebagai PSK. Selain itu, kehidupan dunia 'atas-bawah' mereka yang mencurigakan dan hasrat untuk lebih mempercayai seseorang yang berbagi pengalaman hidup yang sama serta menghadapi faktor risiko yang sama.
Telah diakui bahwa keberadaan peer educator lebih efektif dalam menggali kebutuhan dan persepsi dari para PSK yang merupakan kelompok target daripada pendidik yang berasal dari luar kelompok tersebut. Peers atau teman-teman seprofesi dinilai efektif untuk mewakili komunitas para PSK dan membantu menyalurkan keprihatinan komunitas para PSK tersebut (Astana, Sheena, \& Oostvogels, 1999).

\section{Keberhasilan PSK sebagai pendidik mengenai IMS dan HIV/AIDS bagi pelanggan}

PSK yang telah menjalani VCT dan mendapatkan tambahan informasi dan pengetahuan mengenai HIV/ AIDS berperan sebagai educator bagi teman-teman seprofesi mereka serta educator bagi para tamu atau pelanggan mereka.

Peningkatan kewaspadaan akan HIV/AIDS serta kesadaran bahwa VCT merupakan ujung tombak untuk mengetahui bahwa seseorang telah terinfeksi HIV/AIDS atau belum memberikan dorongan tersendiri bagi PSK untuk turut mempromosikan VCT kepada para tamu dan pelanggan mereka.

PSK menganjurkan para tamu dan pelanggan mereka untuk melakukan VCT guna melindungi kesehatan para tamu dan PSK sendiri dari HIV/AIDS serta meningkatkan pengetahuan para tamu akan bahaya HIV/AIDS dan faktor risiko lainnya yang berkaitan dengan perilaku seks berisiko yang dijalaninya.

Penelitian mengenai faktor risiko HIV dan jaringan sosial di antara komunitas PSK di Boston menyatakan bahwa para PSK sangat menghargai akan kehadiran peer educator karena banyak sekali manfaat yang para PSK dapatkan akan keberadaan peer educator.

Manfaat-manfaat tersebut meliputi adanya alur tukarmenukar informasi mengenai IMS, HIV/AIDS dan cara-cara untuk meminimalisir faktor-faktor risiko yang ada tanpa harus merasa sungkan satu sama lain dan sangat berguna bagi mereka serta adanya teman berbagi yang sama-sama mengerti akan keprihatinan masing-masing karena peer educator juga memiliki latar belakang pengalaman dan kehidupan yang sama dengan komunitas para PSK tersebut (Sari, 2009). 
PSK yang menjadi PE dianggap menggurui oleh teman-teman seprofesinya ketika ingin menyampaikan informasi mengenai IMS dan HIV/ AIDS

Selain mengungkapkan keuntungan akan adanya peer educator, para PSK yang menjadi peer educator juga mengungkapkan adanya keterbatasan dan hambatan yang mereka temui saat mereka berusaha menjalankan peran mereka sebagai peer educator. Para PSK sering mengalami penolakan oleh teman seprofesi mereka saat berusaha membagi informasi mengenai HIV/AIDS dan pencegahannya. Teman para peer educator menganggap bahwa peer educator terlalu menggurui mereka karena peer educator memiliki latar belakang pekerjaan yang sama dengan mereka sehingga timbul ketidakpercayaan terhadap para peer educator.

Sebuah penelitian pada tahun 2009 yang berjudul HIV Risk and Social Networks Among Male-toFemale Transgender Sex Workers in Boston, Massachusetts yang dilakukan pada beberapa PSK transgender menghasilkan kesimpulan bahwa selain informasi mengenai HIV/AIDS para PSK juga menginginkan adanya intervensi lain seperti pelayanan kesehatan mental untuk mereduksi stressor para PSK tersebut. Informasimengenai HIV/AIDS sudah banyak diberikan oleh para peer educator. Namun mereka tidak menemukan cara mereduksi stressor lain yang menjadi penyebab mereka terjun dalam dunia prostitusi karena para PSK tersebut berangkat dari permasalahan yang sama (Sari, 2009).

\section{Kesimpulan}

Kesimpulan dari penelitian adalah para PSK tetap mempertahankan perilaku hidup bersih sehat mereka sehari-hari dan perilaku mencari pelayanan kesehatan serta menjadi peer educator bagi teman seprofesi mereka. Namun, mereka masih mengalami kesulitan untuk mendapatkan kepercayaan dari teman seprofesi serta keterbatasan keterampilan mereka dalam berkomunikasi di depan umum.

Adapun saran-saran yang dapat peneliti berikan berdasarkan hasil penelitian ini adalah pemerintah atau LSM terkait. Sebaiknya mereka membantu mempertahankan perubahan perilaku hidup bersih sehat para PSK. Selain itu, peningkatan kewaspadaan PSK akan faktor risiko pekerjaan yang mereka jalani setelah melakukan VCT dengan mengadakan screening secara berkelanjutan. Disamping itu, pemerintah sebaiknya memberikan tambahan peningkatan skill peer educator dalam menyampaikan informasi mengenai IMS dan HIV/ AIDS dengan pelatihan komunikasi efektif serta pemberian penyuluhan kesehatan yang baik untuk meningkatkan efektivitas peran peer educator dalam komunitasnya (NM, JS, KN).

\section{Referensi}

Asthana, Sheena, \& Oostvogels, R. (1999). Community participation in hiv prevention: problems and prospect for community-based strategies among female sex workers in Madras. Great Britain: Elsevier Science Ltd.

Moleong, L.J. (2002). Metodologi penelitian kualitatif. Bandung: PT. Remaja Rosdakarya.

Sandy. (2008). VCT tonggak hijrah seorang berisiko HIV/AIDS. Diperoleh dari www.jangkar.org/.

Sari. (2009). Penelitian kualitatif: Penelitian tindakan dan penelitian tindakan kelas serta implementasinya di kelas. Diperoleh dari http:/ /www.umpwr. ac.id/publikasi/13analisiskualitatifdalam-penelitian-sosial.

UNAIDS. (2008). AIDS epidemic update. Diperoleh dari http://www.who.int.

Kebanyakan dari kita tidak mensyukuri apa yang sudah kita miliki, tetapi kita selalu menyesali apa yang belum kita capai.

- Schopenhauer - 